\title{
Primary sources for a digital-born history: the Hispanic blogosphere on the Spanish Civil War and Franco's regime
}

\author{
Matilde Eiroa San Francisco \\ Facultad de Humanidades, Comunicación y Documentación, Universidad Carlos III de Madrid, \\ c/ Madrid, 133, edificio 17, 28903-Getafe, Madrid. \\ e-mail:meiroa@hum.uc3m.es \\ ORCID iD: http://orcid.org/0000-0003-0130-5909
}

Submitted: 10 December 2017. Accepted: 21 May 2018

\begin{abstract}
The digital environment has enabled the creation of new genres and formats that give birth to an array of digital-born sources at the disposal of historians. The traditional digitised sources that refer us to conventional archives are now joined by a series of on-line resources with valuable information on the history and culture of today's world, which should not be ignored by the historiography focused on studying the recent past as well as historiography aiming to analyse the dialogues between past and present. In this document, we have chosen one of those sources, blogs, and we propose methodological guidelines for their analysis. Moreover, a specific analysis is proposed on blogs related to the history and memory of the Spanish Civil War and Franco's regime.
\end{abstract}

KEYWORDS: Weblogs; Digital research methods; Historiography; Digital resources; Spanish Civil War; Franco's dictatorship.

Citation / Cómo citar este artículo: Eiroa San Francisco, Matilde (2018) "Primary sources for a digital-born history: the Hispanic blogosphere on the Spanish Civil War and Franco's regime". Culture \& History Digital Journal, 7 (2): e016. https://doi.org/10.3989/chdj.2018.16

RESUMEN: Fuentes primarias para una historia nacida digital: la blogosfera hispana de la Guerra Civil y el franquismo.- El entorno digital ha permitido la creación de nuevos géneros y formatos que configuran un abanico de fuentes nacidas digitales susceptibles de utilizar por los historiadores. A las fuentes tradicionales digitalizadas que remiten a los, archivos convencionales, se unen un conjunto de recursos online con información valiosa sobre la historia y la cultura del mundo actual que no pueden ser obviadas por la historiografía enfocada al estudio del pasado reciente y aquella que pretende analizar los diálogos del pasado con el presente. En el texto que presentamos se ha seleccionado una de estas nuevas fuentes, los blogs, y se proponen pautas metodológicas para su análisis. Asimismo, se plantea un estudio específico de blogs de Historia y Memoria de la Guerra Civil y el Franquismo.

PALABRAS CLAVE: Weblogs; Métodos digitales de investigación; Historiografía; Recursos digitales; Guerra Civil Española; Dictadura de Franco.

Copyright: (C) 2018 CSIC. This is an open-access article distributed under the terms of the Creative Commons Attribution 4.0 International (CC BY 4.0) License.

\section{INTRODUCTION}

Information technologies and novel software that started appearing at the beginning of the 21 st century have facilitated the research process for historians, namely regarding the search and access to documentation and the dissemination of results. Many publications explain the challenges and opportunities that this phenomenon entails and the impact on the work of the academia due to the spread of culture and the practice of the so-called digital history, currently in full growth. ${ }^{1}$ Anaclet Pons (2008), after collecting a dialogue between some of the most re- 
nowned specialists in this field, defined it as the use of new technologies to create, execute or disseminate historical research.

One of the most relevant challenges for historiography rests on the need to incorporate research methods from other social sciences, such as information and communication technologies, without leaving aside the epistemological principles of history. Currently, it is becoming increasingly common for projects to use IT resources to present history in a more visual manner, mediated by the features of the Web 2.0, that is, multimedia, interactivity and hyperlinks. One of the Spanish pioneering examples of this is that of José María Cardesín (2009) on the city of Ferrol, to which diverse initiatives by historians have been added. ${ }^{2}$ However, it is not that frequent to observe the use of digital-born sources, such as websites, blogs, social media and electronic means, even if they are unavoidable when doing research on Current History, historiographic speciality that present an analytic possibility and an intelligibility space of the historic phenomenon based on the present (González, 2015 132). In our opinion, it is necessary to classify the theoretical concepts and heuristics applied to this new type of sources susceptible of being used by historiography.

In line with this, what we propose is to analyse blogs as a potential primary source in order to include this evidence of the current society in the catalogue of historiographic sources. If, after a heated debate, we included in the sixties oral testimonies as valuable heritage of our recent past, we believe that today it is necessary to include digital elements that provide information on contemporary events and that are characteristic of the connected $21^{\text {st }}$ century.

Thus, in this document we propose a theoretical framework and a methodological proposal to analyse this new resource, examining the specific case of those blogs devoted to the Spanish civil war and Franco's regime. We believe that, what we could call the "Blogosphere of History and Memory" constitutes, more than a platform of relations and activities of large communities (Cole, 2011), a virtual place where to find multimedia material on our current times of huge value for research.

\section{BLOGS: NEW RECORDS AND MEDIA OF THE RECENT PAST}

Contemporaneity is one of the eras that has seen a higher number of diversity and multiplicity of sources. According to Aróstegui (1995: 338), historiographic sources are objects coming from human creativity that enable the collection of data and infer an interpretation on a specific social situation. Thus, the universe of conventional resources has been enriched by the arrival of new footprints, such as audiovisual and oral footprints over the last decades of the $20^{\text {th }}$ century, and digital ones, rooting from information technologies at the beginning of the $21^{\text {st }}$ century.

The diversification of new records affects the notion of source, so that those new social expressions widen his- torians' heuristic catalogue and disrupt the way in which they are methodologically studied. One of the most relevant challenges is their identification and classification, as well as the establishment of heuristic parameters able to establish the authenticity, trust and veracity of digital elements. Nevertheless, virtual repositories have gradually spurred up, safeguarding those intangible materials, only accessible electronically. Internet itself already has its own archive where millions of sites with all types of resources are stored, though the problem of their conservation have not been solved. ${ }^{3}$

As well as websites, portals and social media, another element to take into consideration as a source are blogs, short for weblogs, which first appeared with their current format in 1996. The term was coined in 1997 although its widespread use came later, when company Pyra Labs set up a free software that started being used with huge success (Hunsinger, 2010). Blogs can be considered personal websites, but they are more dynamic, based on the principles of microcontent, constant update, irregular frequency, - new text may appear daily, weekly, monthly or may even be on hold for months -, and it has an organizational structure which is in reverse chronological order. This new tool was created as a simplified way to share ideas or knowledge on the internet and could be defined as a diary, or online journal, where authors write their thoughts or information of interest to them in short texts - posts- or long essays, accompanied by photographs, audiovisual recordings, digital resources or press releases. Posts create a chain of thought with different comments and fragments, organised by date and categories that can be reviewed or corrected as required. This option to rectify and readers' interaction through tools that allow you to comment, participate, send links, images or any other material, gains the direct participation in content creation (Efimova and De Mor, 2005). ${ }^{4}$ They sometimes act as a simple virtual journal where authors tell their everyday experiences, whereas in other cases they become a compendium of information linked and commented, coming from different virtual publications.

Cole (2011) states that the act of blogging has a lot in common with the brochures of the $18^{\text {th }}$ and $19^{\text {th }}$ centuries and with the informal newsletters of the Cold War in so much as they expressed subjective opinions and private information. They could be classified as direct and voluntary primary sources in digital format included in the set of testimonial sources of cultural nature, such as old chronicles, memoires and oral testimonies. In any case, they have contributed to the birth of new expression genres that affect the existing set in the widespread dominance of the internet.

Recuero (2003) identifies some of the main typologies: diaries, those that focus mainly on private and everyday matters; publications, focused on giving information and opinion, fostering debate and comments on several issues; literary, focused on disseminating fiction or literary production; clippings, those devoted to collecting and filtering links and news that appear in other publication; and mixed, those that combine posts, information 
and personal opinion. ${ }^{5}$ Herring and Kouper (2005) add to this classification a particular type of blog, the so-called "filter blog", focused on selecting political information disseminated through the web, although some studies have shown that they are not common and nearly $50 \%$ of them do not have links to other weblogs (Herring et al 2004; Wei, 2009 Digital media, as well as many portals, have blogs written by staff journalists or collaborators that use them to introduce new topics or expand on those appearing in the specific medium (Orihuela, 2004). ${ }^{6}$ Other varieties linked to cultural communication, pedagogy, political demands or memory could be added to the basic typology above. The most popular blogs are defined as the "A-list", being the most quoted, read and linked by other bloggers, creating areas of important influence in the digital world.

Media theory on the uses and rewards observes those types as indicative of the way active internet users select content that may meet their needs and motivate someone to create their own page (Papacharissi, 2002). According to some studies (Efimova and de Moor, 2005), they operate as vehicles for self-expression and empowerment by enabling the dissemination of a personal writing space, although its public, on-line nature suggests the need to communicate with readers. Thus the relevance of links to observe the popularity of the creator, easily measurable if we interpret that popularity based on the number of other bloggers who have links to the author. Some authors (Herring et al, 2004) have found a link between the creators' gender and the type of blog. One of their conclusions is the idea that women create blogs with more personal and family content, whereas men prefer filter-type blogs.

Every discipline and profession has taken up this resource according to its needs and interests. In journalism, blogs are therefore considered an alternative source of news and as offering a possibility to expand on content published in the traditional news genres (Colussi, 2013). For educators and businesspeople, blogs represent shared knowledge ${ }^{7}$, whilst historians have used this new content distribution platform for educational activities, namely educational and research material, for the dissemination of research studies and articles, and to inform. ${ }^{8}$ Some even combine academic tasks with cultural, bibliographic and political analysis, such as the blogs created by Anaclet Pons and Justo Serna. ${ }^{9}$ Beyond the Spanish borders, we would like to mention the blogs by Claire Potter, from Wesleyan University, Mark Grimsley, military historian, and Mary Beard, from the University of Cambridge, who mixes the classical period with posts on the contemporary world. ${ }^{10}$ History blogs have their own award-giving infrastructure, the Cliopatria Awards, created in 2005 in the framework of the History News Network of George Mason University. Nevertheless, historians are a minority versus the spread of this democratic format where thousands of people disseminate all kinds of information and resources covering several interests. Thus, it is easy to find numerous virtual journals that show the non-academic authors' passion for history, people who spend their free time doing research, reading and informing on history.
A short article by Henry Jenkins entitled Blog This (2002) was one of the first published on this topic by a known scholar. In the article, he put forward its potential and influence on the current internet configuration, although he showed his distance to them and mistrusted their use for academic or educational purposes. Mortensen and Walker (2002) state that it is an activity similar to the work of a researcher given that authors filter information, choose the topics that interest them or are relevant to them, comment them, show the connections amongst them and analyse them. The internet's potential to enrich knowledge through the spreading of content and the access to that knowledge by any individual who can use the simplified software of a blog, multiplies the possibilities of disseminating a transmedia story about the past (Poyntz, 2010).

Therefore, most blogs are written by independent researchers, scholars or individuals with different backgrounds and interests who wish to share their knowledge and opinion in the digital environment. Some bloggers understand that their work provides valuable information that cannot be found in the academic or media production and post information and material as per their own criteria to make up fragmented stories, even though most of them are connected through references, comments or blogrolls in a huge network that builds its own story (Poyntz, 2010). And it is there that the interest for historiography rests, given that blogs manage to disseminate personal archives created with miscellaneous family or relative materials that refer back to little-known events for history or contribute with resources of different nature that represent current society.

Therefore, the blog phenomenon requires the attention of the academia and historians as it becomes a documentation and information hub, a centre of large community relations and activities by scholars interested in history and in the present times (Cole, 2011).

\section{METHODOLOGICAL PROPOSAL FOR THE ANALYSIS OF BLOGS}

The methodological treatment of this new digital-born source is very complex and raises many questions, ranging from the search to the selection of findings and content analysis. Consequently, as well as the historiographic techniques of synthesis and chronological classification of information, we propose to use the process used by other social sciences, such as the sciences of communication, given that the characteristics of the subject matter and of the internet require it.

The investigation process in the on-line environment must be focused in a similar fashion to the approach for conventional research, that is, the setting of objectives, the drafting of hypothesis and/or research questions, the definition of a theoretical framework and the method to face the empirical work, although with variations due to the particularity of the digital environment where it takes place. Maybe, the most important difference is the search for the subject matter, that in the virtual environment 
must be done through search engines or specialised sites on the matter being analysed.

The search for blogs can be done introducing concepts or keywords in a two-fold fashion: directly in the usual search engine, namely Google, through the services provided by Google Search Advanced (https://www.google. es/advanced_search), and Blog Search Engine (http:// www.blogsearchengine.org/), whose results tend to be quite large and force us to select a sample. We must also search in specialised sites, in platforms such as Hypotheses.org, portal Blogesfera.com, directory laBlogoteca, and social aggregator Bicatoras.com. Depending on the topic, the findings may be scarce, due to the fact that those sites host mainly commercial sites, and very few of historiographic interest.

A second level would be the indirect search through links, where it is easy to observe the network of bloggers joined by common interests. With this dual procedure we achieve a catalogue of digital notebooks that will become the subject matter. Zotero, a free downloadable software (https://www.zotero.org/), will help us organise and record the findings.

Another difference versus conventional research is the classification of the material found and its correct arrangement to facilitate its analysis. Digital databases are the most appropriate support for the above, given that they allows us to establish relations between the information gathered in the searches and the analysis of the interactivity or multimediation, basic characteristics of internet information. There are numerous types of databases simple to use, such as Access or Filemaker, designed namely for the private use of information. But we can also make use of free platforms such as OMEKA (https:// omeka.org/), designed to classify and record information and, especially, to visualize collections of the elements included in digital history projects.

As well as for purposes of classification and conservation of sources, databases can be used as the backbone for the analysis of identification indicators that allow us to discover the blog's credibility as a source. For instance, the author, date of creation, objectives, sources used, links, number of posts and regularity, topics, number of visits, etc. All those fields respond to questions that try to discover the identity of authors, their objectives, reliability of their work, story told, context and interactivity with similar means. Thinking beyond those descriptive fields, it is interesting to find out what content they disseminate and if they are appropriate to be used in historiographic research. An appropriate technique for this could be the so-called text mining, based on the treatment of important amounts of documents that offers the possibility to process and present information in a format that facilitates its understanding and analysis. (Eíto and Senso, 2004).

However, the most common method in blog research is content analysis, a quantitative technique that adapts well to the structure of those virtual notebooks, made up of elements that can be classified. ${ }^{11}$ As for the selection of an analysis unit, blogs provide a series of options in their natural arrangement such as the homepage, that presents the most recent posts, as well as identity data and interactivity - links, number of followers, number of visits, and presence in other social media -. Many provide an archive of initial content, an option that allows researchers to download and save versions of those texts. Finally, their structure includes shared multimedia elements - text, graphics or audiovisual material -. Therefore, the existence of theme categories is feasible and allows us to obtain enough information to assess the way in which they contribute to the knowledge of past and its dissemination.

Nevertheless, the method has obstacles and complications, such as capturing hyperlink content or establishing limits to the units being examined, leading to complex decisions on methodology (Herring, 2010). One of the challenges faced during the conveying of information sometimes has to do with the quotes, comments or even the communication by other media, such as social media. Although some studies (Ali-Hasan and Adamic, 2007; Efimova and De Mor, 2005) have found limited interactivity between weblogs, the truth is that there are complex conversations between them. Jenkins (2002) defines them as accounts that show the preferred topics, the networks created and the influence of participants. Those narrative networks register higher connection periods than others, given that the exchange of information is developed in communities or during specific moments, and those circumstances influence the frequency and topic to study. All this enables the study of people connected and what type of content they exchange, and this is the aspect that leads to greater historiographic attention.

\section{A PRACTICAL CASE: APPROACH FOR THE ANALYSIS OF THE HISPANIC BLOGOSPHERE ON THE SPANISH CIVIL WAR AND FRANCO'S REGIME}

The study we present examines a series of blogs on the civil war and Franco's regime that represent a thick network of bloggers that could be classified as a community, due to the links and interactions amongst participants. Many are aware of the existence of others given that they appear in preferred or followed lists, sometimes they link them to their blogrolls or are connected through Facebook or Twitter.

The purpose of this analysis is to examine who are the authors and what representation of the Civil War and Franco's regime they are disseminating, bearing in mind that they frequently have a higher amount of readers and followers than publications by the most renowned historians. We hypothesize that they are mostly individuals who are not scholars, whose objective is to share through this visual format their private archives - photos, memories, documents-, news on the topic, as well as remembrance activities in which they participate and collaborate. Moreover, we believe their aim is to provide historic knowledge and remembrance activism to the huge network of institutions, groups and associations devoted to those two periods of our recent history. 
The Spanish Civil War and Franco's regime, as it is well known, are historiographic fields of huge interest amongst scholars, but also amongst thousands of people who believe those periods are relevant and wish to disseminate private documents and testimonials to the public knowledge. Those contributions could be encompassed within the so-called postmemory, the memory transmitted by the generation of those who were not witnesses of a time, but lived with the protagonists of those events as close relatives (Hirsch, 1992 and 2012; Quílez and Rueda, 2017), and in the collective memory, that is, the memory created with the information shared based on the memories of witnesses (Halbwachs, 2004). This willingness to pass on history and memories and their dissemination to the general public acquires a specific dimension in the digital public history, defined as an approach that promotes the study and collaborative practice through digital media and technology to democratise history, incorporate new voices and encourage general participation in the presentation and conservation of the past. ${ }^{12}$ It is a publiccentred approach, and the idea is that internet users can play a key role on the side of scholars, and even build sources of historiographic use (Noiret, 2011 and 2015).

The characteristics of the internet and "digital disorder", in the words of Anaclet Pons (2013), prevent the centralisation of blogs on this crucial era of our history. However, the database of the project HISMEDI collects a huge amount of virtual notebooks that exist on the topic, as well as other digital elements such as websites, social media, digital newsletters and Youtube and Vimeo documentaries. ${ }^{13}$ Set up with the free software OMEKA, created by the Center Roy Rosenzweig for History and New Media of the George Mason University (United States), it provides indicators based on the universal system of the Dublin Core element set and the determination of metadata according to the type of element, two aspects that facilitate and complete the analysis of the blogosphere. ${ }^{14}$ Under the title "Blogopshere on the Spanish Civil War and Franco's regime", it is made up of a set of 243 blogs classified until the $27^{\text {th }}$ of August 2017, devoted specifically to this topic, having ruled out many blogs on history, culture or politics that at some point published in their posts information on new publications or news on both eras of our history.

\section{Who are the bloggers of history and memories?}

The profile of those blogosphere authors is a heterogeneous group that understands their creation as a tool to express themselves in public and communicate with each other.

This community is mostly made up of a set of groups, foundations and associations, followed by individual men and women. As can be observed in Graph 1, it must be noticed that a large amount of them do not reveal their identity or use a pseudonym, mainly to avoid being in a vulnerable situation when faced with criticism. Given that they are private notebooks, they are a self-representation of thoughts and opinions of those choosing to expose their personal profiles (Qian, 2007: 1428). However, in terms of their use as a historiographic source, the anonymity or use of fake names leads to lack of credibility and mistrust by the researcher. Other authors are the mainstream media, research teams or public institutions, whose presence in this area is limited due to the blogs' personal and dynamic nature.

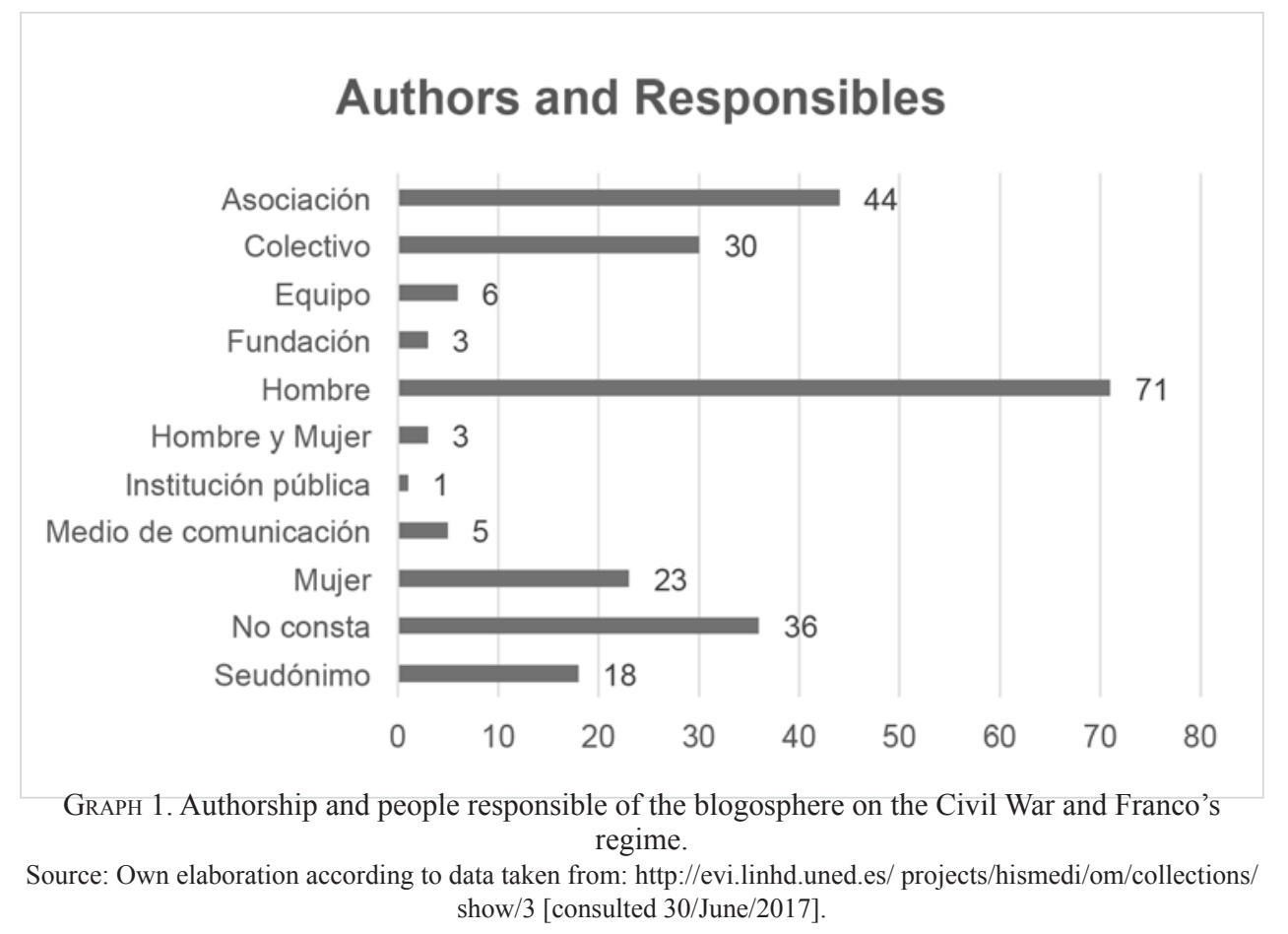

Culture \& History Digital Journal 7(2), December 2018, e016. eISSN 2253-797X, doi: https://doi.org/10.3989/chdj.2018.016 
Individuals, whether men or women, are the biggest category, thus confirming the unique and subjective nature of those virtual notebooks. We must highlight that some female bloggers have several sites with specialised information. That is the case of $\mathrm{M}^{\mathrm{a}}$ José Barreiro, in charge of eight, or María Torres, administrator of two and collaborator of two others. Some are characterised for constantly updating their content such as Cristina Calandre, quite prolific in her writing on the history of her grandfather. ${ }^{15}$ Some studies (Herring and Paolillo, 2006) have valued the gender differences in terms of design and content, something that cannot be confirmed by the blogs written by women on the Civil War and Franco's regime. However, it is possible to establish that female bloggers mostly devote their sites to their family members, either to pay tribute to their ancestors who were executed, or who disappeared or went into exile, or to stolen children or what we could consider more private matters linked to family history.

Some have achieved a relevant social position that can be seen based on the centrality - or node - of their blog when looking at all the members of a network. Popularity is easily measurable if we interpret it as the number of weblogs that are interlinked and, thus, the quotes received. Many know of the existence of others because they appear on their lists of preferred or followed blogs, or because they include links to them or are connected through social media. However, some authors do not offer that data or the number of followers or visits, thus preventing us from confirming their popularity and, to certain degree, credibility.

With regard to the date of creation, the first blogs found on the topic were created in 2004 and their growth, as can be seen in Graph 2, started after 2006. The year 2010 saw the highest number of blogs created (33) followed by 2008 (31) and 2009 (26), corresponding to the last mandate by the government of former Prime Minister José Luis Rodríguez Zapatero. Since then, they have decreased until the lowest figure of blog creation, reached in $2017 .^{16}$

However, this chronology does not correspond with the number of posts published. Since 2012, the dissemination of content has increased, partly due to the dynamism of the remembrance movement in the years of Mariano Rajoy's government, after he put on hold the Law on Historical Memory of 2007. Some bloggers consider their blogs an antidote to the silence imposed by politicians or due to the lack of memory policies in Spain, and they present themselves as independent speakers in an adverse situation. With this in mind, they have taken on the role of transmitters of activities and news on topics linked to the assertion of memories, intensifying their contribution of private materials to demand attention to the victims of Franco's regime.

The blogoshpere on the Spanish Civil War and Franco's regime has observed an important interactivity in two levels: on the one hand, the connections with wellknown associations with great remembrance activity, and on the other, links to websites specialised on specific topics or on limited geographical areas, such as the Siege of Madrid, the Battles of the Ebro, of Brunete or of the Jarama. That is, they prefer to be linked to groups or associations that have a predominant position in the collective demand rather than being linked to similar bloggers. With the links collected in each blog, a list has been made and divided into an A-list, and a B-list, corresponding to the most-linked blogs and those with the highest amount of readers, thus leading to an important notoriety amongst followers and, in consequence, considered to be a referent. Table 1 shows both lists, the A-list includes the sites of associations or national groups that attract the attention of bloggers. The B-list includes some female individual

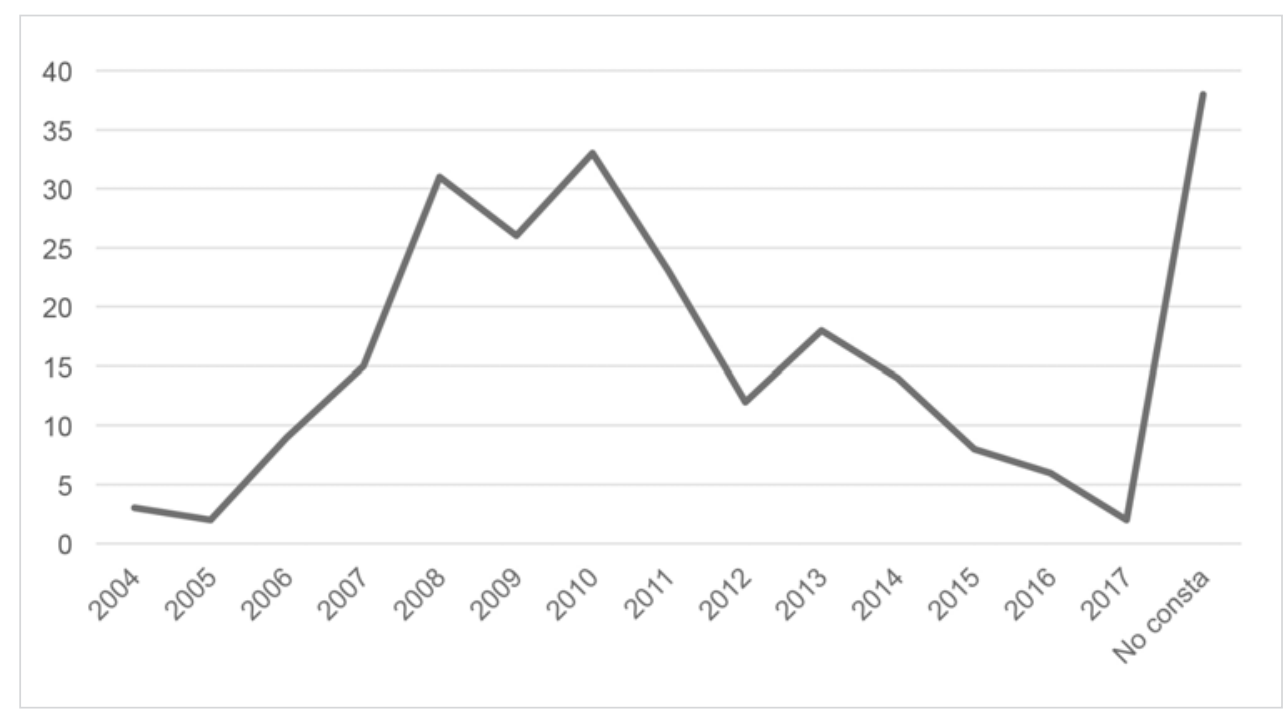

GRAPH 2. Dates of creation of the Blogosphere on the Civil War and Franco's regime.

Source: Own elaboration according to data taken from: http://evi.linhd.uned.es/projects/hismedi/om/ collections/show/3 [consulted 30/June/2017]. 
TABLE 1. Connections between bloggers.

\begin{tabular}{|l|l|}
\hline \multicolumn{1}{|c|}{$\begin{array}{c}\text { A-List } \\
(20-30 \text { links })\end{array}$} & \multicolumn{1}{c|}{$\begin{array}{c}\text { B-List } \\
(19-9 \text { links })\end{array}$} \\
\hline ARMH & Todos los Rostros \\
\hline Foro por la Memoria (distintas agrupaciones) & Búscame en el ciclo de la vida \\
\hline Federación de Foros por la Memoria & Arqueología de la Guerra Civil \\
\hline Todos los Nombres & (Re)generando Memorias \\
\hline & Público, Memoria Pública. \\
\hline
\end{tabular}

Source: Own elaboration according to data taken from: http://evi.linhd.uned.es/projects/hismedi/om/collections/ show/3 [consulted 30/June/2017].

authors - Búscame en el ciclo de la vida and (Re)generando memorias -, as well as the digital daily Público, a very well known media amongst the social movement in favour of historical memory. Nevertheless, it must be observed that there is not a lot of blogosphere connectivity given that the most linked blogs included in both lists make up a small number compared to those that are not linked or those that have unidirectional connections to local blogs on common matters.

This limited interactivity does not mean that there are no conversations amongst them, that is, interconnected posts and comments on a specific topic through other means such as distribution lists. Thus, they make up an account that shows the content being created, not just with the contribution of their materials, but with the addition of those produced by others, as well as the networks created and the participation of followers that sometimes contribute with comments or data

\section{Functions and content}

The functions fulfilled by the Blogsohpere on the Spanish Civil War and Franco's regime are varied and provide many services to their readers. Generally, they disseminate documents held in family archives, events in locations that do not appear in general history books, cultural news or demands. The main function is to inform, followed by the presentation of demands and information regarding the activities of the remembrance movement. We can even find virtual notebooks with leisure and entertainment purposes as they include in their content collections of posters, stamps, weaponry or war games. Contrary to this, very few, the so-called "clipping" and "filter" blogs (Herring and Kouper, 2005), act as brief information newsletters that appear in digital dailies or the Memory blogosphere. ${ }^{17}$ Very few too are used for authors' self-propaganda, using the space to promote their work. ${ }^{18}$ Or those manipulating the facts of the past with the aim to misinform or cause controversy. ${ }^{19}$

Moreover, there are some blogs that could fulfil a historiographic function as they are configured as a register of text or audiovisual digital resources on the past. Generally, this function corresponds to those devoted to specific people, not well known by the general public. An exam- ple of this is the dissemination of the work and merits of Doctor Calandre, the one created to pay tribute to Manuel Barreiro Rey, a naval officer executed in the Naval Base of El Ferrol in April 1939, or that of Juan José del Águila entitled Justicia y Dictadura, of an autobiographic nature and with resources on the Social-Political Brigade, with rulings or information on the Grimau case. ${ }^{20}$

However, the capability to publish on history does not turn the blogger into a historian. The authors of those blogs are not obliged to meet the methodology demands or ethics of history, such as the commitment to obtain the information from archives or to compare sources. In numerous occasions they are loaded with their own individual opinions, with the use of the first person in their narrative, the inclusion of pictures and other materials that visually identify the authorship. This type of elements entail at least a challenge for historians, as they have to approach the materials exposed in the open with a professional lens and, therefore, must subject them to the due tests of verification of the content they disseminate.

The features of those blogs, such as interactivity when they allow followers to send comments, subscribe to news or contact by e-mail -, the multimedia aspect -dissemination of audiovisual and digitised resources to support their statements - and hyperlinks - to public institutions, media, archives, legislation or any source they believe can back their information - help to determine their credibility. The public nature of the content allows anyone to read and correct or report the information given, which is also a way to find out the acknowledgement of followers.

As for the content distributed, it could basically be divided into two main categories. The first one would include those blogs of interest for historiography because they disseminate posts with content and resources on military history, or on several aspects of social history, "from-below" history, or the dissemination of results on research projects. We are referring to those that comment aspects on battles, bombings, the siege of various locations, the material heritage of the conflict, people who disappeared, were executed, concentration camps, antifascist resistance or microbiographies accompanied by audiovisual resources. In Halbwachs's opinion (2004), personal experience would just become a simple anecdote 
if it were not part of a community, thus individuals share the memories of their biographical experiences with those alike. Some of the blogs that represent this category, as well as those mentioned above, are: Arqueología de la Guerra Civil Española, Historia de los uruguayos en la GCE, El blog de los fusilados en el Monte Estépar (Burgos), Hispanoamericanos en la Guerra Civil Española, Guadalajara en guerra, batallas entre italianos, Cartes a Francesca, 1938-1943, Pedra i paper. Històries del Maresme, Microbiografías (Guerrilla Antifranquista en Cantabria), Fusilados de Torrellas, José Suárez Montero, Todos los Rostros, lasmerindadesenlamemoria o Memorial de la Orbada. ${ }^{21}$ This classification could also encompass those that inform about new publications or historiographic discussions, such as the blogs of historians Ángel Viñas and Lucía Prieto. ${ }^{22}$

A second category would be blogs referring to advocacy and remembrance activities of associations, groups and individuals, which would include blogs with posts on remembrance activities, tributes, protests, demonstrations and advocacy seminars. Amongst them we should mention Coordinadora para la Memoria Histórica $y$ Democrática de Madrid, Memória a Borriana, Veritat, justicia i reparació. Dret a decidir, AMHYJA, Germán el Rojo, Toño, Un país sin franquismo, Memoria Histórica de Ciudad Real, Fills et filles de Republicains Espagnoles et enfants de l'exode, Buscamos a Francisco, Asociación Héroes de la República y la Libertad, etc. ${ }^{23}$ In their texts it is easy to see the convergence of the victims' demands to have a right to their memories, truth, justice and reparation as well as collective memory, that is, the will to share memories of the past. Those advocacy blogs on memory express the way in which society builds a sense of the past, explores and defines the experience of a specific event, normally a traumatic one, as is the case of the survivors of the Holocaust. In this process, many memories appear because the others evoke them, and some experiences that were kept in the dark come to the fore of the public arena. At the same time, they are the representation of historic personal experiences and their construction in a constructed knowledge by subsequent generations is what we could call "instruments of memory" such as commemorations, photographs, exhibitions, films or virtual creations. ${ }^{24}$

Collective memory becomes, in the case of the blogoshpere that we are studying, "historical memory", a concept applied to situations developed when the policies on memory are not enough to solve a conflictive past (Aróstegui, 2004; Ruiz Torres, 2007). It suggests acting on the past and implies demanding its readjustment and the construction of a new discourse that includes the actors excluded from the official discourse. Memory reappears and becomes a resource of agitation and advocacy for those who, for a long time, were left out of history. However, Ruiz Vargas (2008) states that the terms collective memory and historical memory lack epistemiological justification. Nevertheless, he finds in historical memory the development of a social, political and ethical function that makes it necessary in order to claim the rights of the victims of Franco's regime, due to them as citizens and anti-fascist fighters.

Those two large topics - history, advocacy activity and collective memory - contain great wealth of content, showed by the great variety of topics of social and academic interest. From the International Brigades to the large and small battles, the multiple arms of violence and the distortion of daily lives due to the war and the establishment of Franco's regime. The key challenge to use them is that the account they offer is fragmented, both when disseminated on the posts or as comments. The reason for this is the nature of this digital format, already described at the beginning, that forces authors to write in a way so that the understanding of the post does not rely on having read the previous one, but it must allow for readers to follow the topic thread. In many occasions there is lack of context, disseminating resources without proper explanation that could contextualise the character or the events in space and time. This fragmentation makes it difficult to apply the method of historic synthesis and forces the use of more stable and generic sources that enable the reconstruction of the past with greater consistency. In most cases, they can be interesting as complementary information, as a type of digital testimonial and transmedia of the subject matter. All in all, they represent an array of historical events, sometimes well known, and other times mainly ignored, although the dominating concept is memory, as it can be observed in the word cloud of Image 1 .

\section{CONCLUSIONS}

Thus, in our opinion, those new virtual elements are a primary source given that they make up evidence of a digital society which dominates current times, that has to be subjected to the necessary analysis and comparison of the data offered, as with any other conventional source. Despite the challenges presented to historians - volatility, content fragmentation and lack of credibility -, a key step

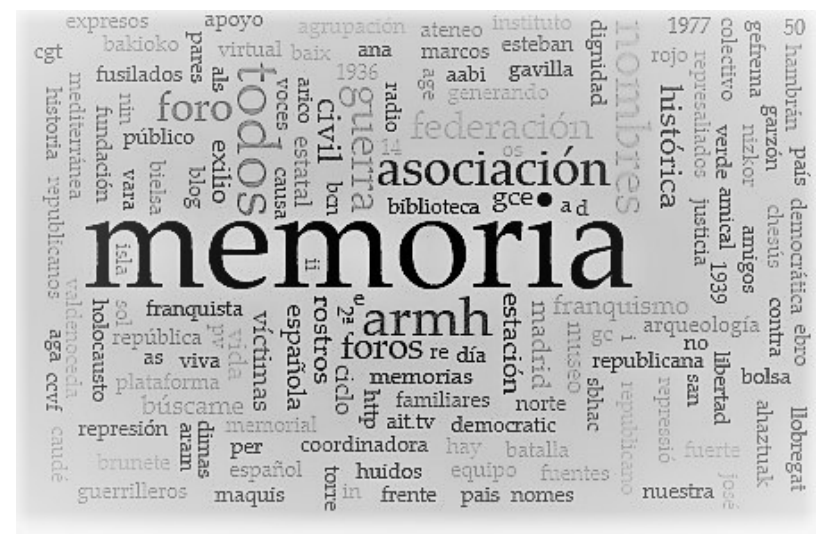

IMAGE 1. Main concepts on the blogosphere on the Civil War and Franco's regime.

Source: Own elaboration according the data taken from http://evi.linhd. uned.es/projects/hismedi/om/collections/show/3 [consulted 27/ June/2017] 
to overcome them is to understand their nature and propose methodological strategies that, based on the rich disciplinary experience, adapt to the demands of the new societies.

In some of the professional specialities that use blogs more frequently, as in Journalism, it seems that they will remain linked to the big media headlines as an expression of the opinion of their authors and as a deeper explanation of current news. Among historians it seems that its use is spreading, encouraged by the possibility of interacting better with students or exposing their research. The https://hypotheses.org/ platform, which houses thousands of social science and humanities blogs, sees the number of visits grow each year and is enriched with academic content in various languages. Other blogospheres are experiencing the same process, as there are more and more profiles trained in Internet tools.

The blogosphere on the Spanish Civil War and Franco's regime allows us to compare the possibilities to use blogs to research the remembrance movement, the events of territorial history, the trajectories of ordinary citizens and the social, political and cultural implications that those two important Spanish history milestones had. In the same manner as with traditional sources, it is necessary to identify the most appropriate digital notebooks for the research in question, but it is obvious that the History of Present Time will have to pay attention to this new format, that, together with others, expresses the dynamics and discussions of our contemporary society.

\section{ACKNOWLEDGEMENTS}

This article is one of the result of the project Historia y Memoria Histórica on line ("Retos y oportunidades para el conocimiento del pasado en Internet ("History and Memory on-line: Challenges and opportunities for the knowledge of the past on the Internet") (HISMEDI), with reference HAR-2015-63582-P MINECO/FEDER. It has been enriched with the resources obtained during the research stay at the Department of Roman Languages and the Metalab of the University of Harvard in the summer of 2017.

\section{NOTES}

1 As we are dealing with a large number of contributions disseminated in monographs, scientific journals and other academic publications, we will only refer to a brief selection of them, such as Fernández Izquierdo (2006), Gallini y Noiret (2011), Melo (2011) y Pons (2011 y 2013).

2 http://journals.cambridge.org/fulltext content/supplementary/ UHY/supp1/esp/ferrol1-noflash.html [consulted 04/July/2017].

3 Accesible in: https://archive.org/

4 See the "Informe sobre el estado de la blogosfera hispana". Bitacoras.com, 2011, http://gplsi.dlsi.ua.es/proyectos/webeso/pdf/informe estado blogosfera hispana.pdf [consulted 24/July/2017].

5 In the platform http://hypotheses.org/, are included blogs from the academical community where to watch these functions [consulted 04/July/2017].

6 This is the case of El Pais cultural blog dedicated to history in which collaborate Tereixa Constenla, Isabel Burdiel, Julián Casanova, Manuel Morales, $\mathrm{M}^{a}$ José Turrión, Javier Herrero and Eduardo Manzano. http://blogs.elpais.com/historias/. [consulted 10/JulY/2017].

7 The blogosphere Bitacoras.com had in 2011576.681 indexed blogs and 204.312 registered blogers. See at: http://bitacoras. com/informe [consulted 24/July/2017].

8 In the url https://bloggingforhistorians.wordpress.com/ offer help and orientation to the historians who wishes to create their own blog.

9 Anaclet Pons's Blog at: (http://clionauta.hypotheses.org/14010); Justo Serna (https://justoserna.com/) [consulted 28/July/2017].

10 Mary Beard is a professor of classical studies and author of the blog A Don's Life, published in The Times as a regular column. See at: https://www.the-tls.co.uk/category/a-dons-life/ [consulted 28/July/2017].

11 Among others, they have used it in their studies (Ali-Hasan, 2007), (Cole, 2011), (Colussi, 2013), (Efimova, 2005), (Herring, Kouper, et al., 2005), (Jensen, Schau y Gilly, 2003) (Mortensen, 2002) (Poyntz, 2010).

12 See the definition at: https://clionauta.wordpress.com/2010/06/25/ la-historia-digital-y-la-historia-publica/. [consulted 28/July/2017].

13 Webpage of resources at: http://uc3m.libguides.com/hismedi and the database included http://evi.linhd.uned.es/projects/hismedi/om/ [consulted 27/July/2017].

14 Software at: https://omeka.org/

$15 M^{a}$ José Barreiro's Blog are at:: http://evi.linhd.uned.es/projects/hismedi/om/search?query=Barreiro\&query type=keyword\&submit_search=Buscar María Torres' Blog, called, Búscame en el ciclo de la vida (http://www.buscameenelciclodelavida.com/) is one of the most linked. Cristina Calandre's Blog is at: http://evi.linhd.uned.es/projects/hismedi/ $\mathrm{om} / \mathrm{search}$ ?query $=$ Calandre\&query_type $=$ key-word\&submit search=Buscar [consulted 30/July/2017].

16 We want to insist the fact that the analysis has been carried out until the date of August 27, 2017.

17 In this typology we could included Jordi Grau's blog: http://evi. linhd.uned.es/projects/hismedi/om/items/show/3 [consulted 30/ July/2017].

18 An example at: https://yofuipresadefranco.wordpress.com/. It began as advertising of Fernando Cardero Azofra and Fernando Cardero's book titled Yo fui presa de Franco (2015) about 151 jailed women in Burgos [consulted 10/April/2018].

19 Among other cases, we could mention the blog "La otra memoria histórica": http://hayotramemoria.blogspot.com.es/ or the one of the Asociación para la Divulgación de la Verdad Histórica: http://divulgacion-historica.blogspot.com.es/ [consulted 10/ April/2018]

20 See at Juan José del Águila: https://justiciaydictadura.com/ [consulted 01/August/2017].

21 The url of all them at: http://evi.linhd.uned.es/projects/hismedi/ om/ [consulted 21/August/2017].

22 Ángel Viñas's blog at: http://www.angelvinas.es/ and Lucía Prieto's at: https://luciaprieto.wordpress.com/blog/ [consulted 21/ August/2017].

23 The url of all them at: http://evi.linhd.uned.es/projects/hismedi/ om/collections/show/3 [consulted 21/August /2017].

24 Authors such as Yosef Hayim Yerushalmi call them "vehículos de memoria". See his book Zakhor: Yewish History and Yewish Memory, New York, 1989.

\section{REFERENCES}

Ali-Hasan, Noor and Adamic Lada (2007) "Expressing social relationships on the blog through links". International Conference for Weblogs and Social Media. https://pdfs.semanticscholar. org/3d2c/edea71a4ba40d87e67e1ad4f3cb73b40c77f.pdf [consulted 04/July/2017].

Aróstegui, Julio (1995) La investigación histórica: teoría y método. Barcelona, Crítica.

Aróstegui, Julio (2004) "Retos de la memoria y trabajos de la historia". Pasado y Memoria. Revista de Historia Contemporánea, 3: 5-58. 
Cardesín, J. M. (2009) “De 'Ferrol Urban History' a la 'Historia Urbana de Galicia': explorando la relación entre memoria, imagen y espacio urbano a través de la Web". Historia Contemporánea, 39: 403-432. http://www.ehu.eus/ojs/index.php/HC/ article/view/2370 [consulted 09/July/2017].

Cole, Juan (2011) "Blogging Current Affairs History". Journal of Contemporary History, 46, 3: 658-670. doi: 10.1177/0022009411403341.

Colussi, Juliana (2013) "Propuesta metodológica para el análisis de blogs periodísticos". Intercom-Revista Brasileira de Ciências da Comunicaçao, 36 2: 197-218. doi: http://dx.doi.org/10.1590/ rbcc.v36i2.1789

Efimova, Lilia and De Mor, Aldo (2005) "Beyond personal webpublishing: an exploratory study of conversational blogging practices". Proceedings of the 38th Hawaii International Conference on System Sciences, Hawaii https://pdfs.semanticscholar. org/b890/3558cf782560fef1d7385ca5b471796bd128.pdf. [consulted 27/June/2017]

Eíto, Ricardo and Senso, José (2004) "Minería textual". El Profesional de la Información, 13,1: 11-27.

Fernández Izquierdo, Francisco (2006) "Investigar, escribir y enseñar Historia en la era de Internet". Hispania. Revista española de Historia, LXVI, (222): 11-30. http://digital.csic.es/handle/ $10261 / 14623$ [consulted 15/June/2017].

Gallini, Stefanía y Noiret, Serge (2011) "La historia digital en la era de la Web 2.0. Introducción al dossier Historia digital". Historia Critica, 43: 16-3. http://www.redalyc.org/articulo.oa?id=81122475003 [consulted 10/June/2017].

González, Magdalena (2015) "La teorización de Julio Aróstegui sobre la historia del tiempo presente como historia vivida". Hispania Nova 13: 126-133. https://e-revistas.uc3m.es/index.php/ HISPNOV/article/view/2398. [consulted 27/June/2017].

Halbwachs, Maurice (2004) La Memoria Colectiva. Prensas Universitaria de Zaragoza, Zaragoza.

Herring, Susan (2010) "Web content analysis: expanding the paradigm". In International Handbook of Internet Research, editado por Hunsinger, Jeremy. Springer Verlag, London: 233-249.

Herring, Susan; Kouper, Inna; Paolillo, John; Scheidt, Lois Ann; Tyworth, Michael; Welsch, Peter; Wright, Elijah and Yu, Ning (2005) "Conversations in the Blogosphere: An Analysis 'From the Bottom Up'". Proceedings of the 38th Hawaii International Conference on System Sciences, Hawaii. https://www.computer. org/csdl/proceedings/hicss/2005/2268/04/22680107b.pdf [consulted 20/May/2017]

Herring, Susan and Paolillo, John (2006) "Gender and genre variation in weblogs". Journal of Sociolinguistics, 10: 439-459.

Hirsch, Marianne (1992) "Family pictures: Maus, Mourning and Postmemory". Discourse. Journal of Theoretical Studies in Media and Culture, 15 (2): 3-29.

Hirsch, Marianne (2012) The generation of post memory: writing and visual culture after the Holocaust. Columbia University Press, New York.

Hunsinger, Jeremy (2010) International Handbook of Internet Research. London, Springer Verlag.

Melo, Jairo Antonio (2011) "Historia digital: la memoria en el archivo infinito". Historia Crítica, 43: 82-103. http://www.redalyc. org/articulo.oa?id=81122475006 [consulted 30/May/2017].
Jenkins, Henry (2002) "Blog this: digital renaissance". MIT Technology Review: Emerging Technologies and Their Impact, 1-3. https:/www.technologyreview.com/s/401372/blog-this/ [consulted 20/May/2017].

Mortensen, Torill and Walker, Jill (2002) "Blogging thoughts: personal publication as an online research tool". In Researching ICTS in Context, editado por Morrison, Andrew. University of Bergen Library, Oslo: 249-279.

Noiret, Serge (2011) "La "Public History": ¿una disciplina fantasma?" Memoria e ricerca 37: 5-7.

Noiret, Serge (2015) "Historia digital e historia pública". In La historiografía ante el giro digital: reflexiones teóricas y prácticas metodológicas, editado por Bresciano, Juan Andrés y Gil, Tiago. Ediciones Cruz del Sur, Montevideo: 41-76.

Orihuela, José Luis (2004) "Datos para un anuario de la blogosfera hispana". Ecuaderno, https://www.ecuaderno.com/2004/06/22/ datos-para-un-anuario-de-la-blogosfera-hispanal [consulted 20/ May/2017]

Papacharissi, Zizi (2002) "The Self Online: The Utility of Personal Home Pages". Journal of Broadcasting and Electronic Media, 46 (3): 346-368. doi: http://dx.doi.org/10.1207/s15506878jobem4603_3

Pons, Anaclet (2008) "Los retos de la historia digital". Clionaut: blog de historia. http://clionauta.wordpress.com/2008/12/03/ los-retos-de-la-historia-digital/. [Consulted 20/May/2017].

Pons, Anaclet (2011) "Guardar como: la historia y las fuentes digitales”, Historia crítica, 43: 38-61. http://www.redalyc.org/ articulo.oa?id=81122475004 [Consulted 20/May/-2017].

Pons, Anaclet (2013) El desorden digital. Guía para historiadores y humanistas. Siglo XXI, Madrid.

Poyntz, Nicholas (2010) "History Blogs", History Today, 60, 5: 37.

Qian, Hua (2007) "Anonymity and self-disclosure on weblogs". Journal of Computer-Mediated Communication (12): 14281251. doi: http://dx.doi.org/10.1111/j.1083-6101.2007.00380.x

Quílez, Laia and Rueda, José Carlos (editores) (2017) Posmemoria de la Guerra civil y el Franquismo. Narrativas audiovisuales y producciones culturales en el siglo XXI. Comares, Granada.

Recuero, Raquel da Cunha (2003) "Warblogs: Os Blogs, a Guerra no Iraque e o Jornalismo Online". Verso e reverso. Revista da Comunicaçao, 17, 37: 1-14.

Ruiz Torres, Pedro (2007) "Los discursos de la memoria histórica en España". Hispania Nova, 7. http://hispanianova.rediris.es/7/ dossier/07d001.pdf [Consulted 25/May/2017].

Ruiz Vargas, José María (2008) “¿De qué hablamos cuando hablamos de «memoria histórica»? Reflexiones desde la psicología cognitiva”. Entelequia. Revista interdisciplinar, 7: 53-75.

Schau, Hope Jensen and Gilly, Mary C. (2003) "We Are What We Post? Self-Presentation in Personal Web Space". Journal of Consumer Research, 30, 3: 385-404. http://www.jstor.org/stable/ 10.1086/378616 [Consulted 20/May/2017].

Trammell, Kaye and Keshelashvili, Ana (2005) "Examining the new influencers: a self-presentation study of A-List Blogs". Journalism and Mass Communication Quarterly, 82, 4: 968-982.

Wei, Lu (2009) "Filter blogs vs. Personal Journals: understanding the knowledge production gap on the Internet". Journal of Computer Mediated Communication (14): 532-558. doi: http:// dx.doi.org/10.1111/j.1083-6101.2009.01452.x 